Short Communication

\title{
Assessing amendment properties of digestate by studying the organic matter composition and the degree of biological stability during the anaerobic digestion of the organic fraction of MSW
}

\author{
Fulvia Tambone*, Pierluigi Genevini, Giuliana D’Imporzano, Fabrizio Adani* \\ Dipartimento di Produzione Vegetale, Università degli Studi di Milano, Via Celoria 2, 20133 Milano, Italy
}

\section{A R T I C L E I N F O}

\section{Article history:}

Received 23 September 2008

Received in revised form 6 February 2009

Accepted 7 February 2009

Available online 9 March 2009

\section{Keywords:}

Anaerobic digestion

Organic matter

Digestate

${ }^{13} \mathrm{C}$ CPMAS NMR

Biological stability

\begin{abstract}
A B S T R A C T
The transformation of organic matter during anaerobic digestion of mixtures of energetic crops, cow slurry, agro-industrial waste and organic fraction of municipal solid waste (OFMSW) was studied by analysing different samples at diverse points during the anaerobic digestion process in a full-scale plant. Both chemical (fiber analysis) and spectroscopic approaches $\left({ }^{13} \mathrm{C}\right.$ CPMAS NMR) indicated the anaerobic digestion process proceeded by degradation of more labile fraction (e.g. carbohydrate-like molecules) and concentration of more recalcitrant molecules (lignin and non-hydrolysable lipids). These modifications determined a higher degree of biological stability of digestate with respect to the starting mixture, as suggested, also, by the good correlations found between the cumulative oxygen uptake $\left(\mathrm{OD}_{20}\right)$, and the sum of (cellulose + hemicellulose + cell soluble) contents of biomasses detected by fiber analysis $(r=0.99$; $P<0.05)$, and both $\mathrm{O}$-alkyl-C $(r=0.98 ; P<0.05)$ and alkyl-C $(r=-0.99 ; P<0.05)$ measured by ${ }^{13} \mathrm{C}$ CPMAS NMR.
\end{abstract}

(c) 2009 Elsevier Ltd. All rights reserved.

\section{Introduction}

The interest in anaerobic digestion (AD) has increased a lot in recent years and the number of anaerobic treatment plants in Europe has remarkably increased (Hansen et al., 1999; Tani et al., 2006).

$\mathrm{AD}$ is a biological process by which, in the absence of oxygen, organic matter is transformed into biogas which principally consists of methane (50-80\% v/v) and carbon dioxide, of which the former can be used to produce energy and heat. The use of biomass in the $\mathrm{AD}$ resulted, also, in the production of a residual organic matrix, i.e. digestate (Tani et al., 2006; Zhang et al., 2007) that could be used in agriculture as nutrient fertilizers and/or organic amendment. Amendment properties of biomass are related to the ability of the contained organic matter to contribute in maintaining the soil humus balance (Magdoff and Weil, 2004). This ability depends by the degradability of the organic matter, i.e. recalcitrance $v s$. labile organic fraction contents (Kögel-Knabner, 2002). An indirect measurement of the degradability of a biomass is the detection of the degree of the biological stability (Lasaridi and Stentiford, 1998). Biological stability determines the extent to which biodegradable organic matter has decomposed (Lasaridi and Stentiford, 1998). A biomass rich in recalcitrant organic molecules is characterized by a high biological stability degree.

\footnotetext{
* Corresponding authors. Tel.: +39 02 50316545; fax: +3902 50316521.

E-mail addresses: fabrizio.adani@unimi.it, fulvia.tambone@unimi.it (F. Tambone).
}

The aim of this short communication was to assess the potentiality of digestate to act as organic amendment by a first description of the organic matter composition (recalcitrant $v s$. labile fraction contents) and of the degree of biological stability of digestate before and after anaerobic digestion of a mixture composed of energetic crops, cow slurry, agro-industrial waste and the organic fraction of municipal solid waste (OFMSW).

\section{Methods}

\subsection{Chemical characteristics}

The samples analysed were obtained from a full-scale biogas production plant located in Lombardy Region (North Italy). The plant, with a treatment capacity of $30,000 \mathrm{Mg}$ year $^{-1}$, produces $2 \mathrm{MW}$ of electrical power by co-digesting, in four continuously stirred thermophilic reactors tanks (CSTR) (hydraulic retention time - HRT of 30-40 d) and in a post-digester (HRT of $50 \mathrm{~d}$ ) a mixture of energetic crops $(1.9 \pm 2.9 \%$ of fresh matter, FM), cow slurry $(21.8 \pm 12.5 \% \mathrm{FM})$, agro-industrial waste $(17.9 \pm 15.6 \% \mathrm{FM})$, and the organic fraction of municipal solid waste (OFMSW) $(58.4 \pm 25.4 \%$ FM).

Samples analysed were divided into three groups. The first group of samples (Group A) represented the feed-in mixture (ingestates) of the biogas plant. The second group (Group B) represented the mixture taken from digesters treatment. Finally, the third 
group of samples (Group C) corresponded to the outgoing material from the post-digesters, approximately after $50 \mathrm{~d}$ of anaerobic digestion. For Group A, B and C, 9, 10 and 10 samples were taken, respectively, over a period of 7 months.

All the samples were dried for $24 \mathrm{~h}$ at $105^{\circ} \mathrm{C}$ (APHA, 1992) and shredded in a blender to pass through a $2-\mathrm{mm}$ mesh. Both biological and chemical analyses in this study were performed using the same dried and shredded samples.

Fresh matter (FM), total solids (TS), volatile solids (VS) and total organic carbon (TOC) were determined according to standard procedures (APHA, 1992). Ammonia $\left(\mathrm{NH}_{3}-\mathrm{N}\right)$ and total nitrogen (NTK) (detected on fresh material) were determined according to the analytical method for wastewater sludges (IRSA CNR, 1994). All analyses were performed in triplicate.

Fiber analyses were performed for neutral detergent fiber (NDF), neutral detergent acid detergent fibers (NDADF) and acid detergent lignin (ADL), following the method described by Van Soest et al. (1991). Cell solubles (CS), lignin plus non-hydrolysable lipid (ADL), cellulose (NDADF-ADL) and hemicellulose (NDFNDADF) were calculated according to Van Soest et al. (1991).

Mass balance for VS, TOC and fiber analyses fractions was performed by ash preservation methods (Genevini et al., 1997).

\section{2. ${ }^{13} \mathrm{C}$ CPMAS NMR analysis}

Spectroscopic investigations were performed on a representative sample obtained by mixing an equal amount of the different sub-samples corresponding to the three samples groups (Groups $\mathrm{A}, \mathrm{B}$ and $\mathrm{C}$ ). The solid-state ${ }^{13} \mathrm{C}$ CPMAS NMR spectra on solid samples were acquired at $10 \mathrm{kHz}$ on a Bruker AMX 600 spectrometer (Bruker BioSpin $\mathrm{GmbH}$, Rheinstetten) using a $4 \mathrm{~mm}$ CPMAS probe. The pulse repetition rate was set at $0.5 \mathrm{~s}$, the contact time at $1 \mathrm{~ms}$ and the number of scans was 3200 . The chemical shift scale of ${ }^{13} \mathrm{C}$ CPMAS NMR spectra was referred to tetramethylsilane ( $\delta=0 \mathrm{ppm})$. More details relative to this technique are reported in Conte et al. (1997).

\subsection{Biological stability tests}

The biological stability of samples was determined by two methods: (i) the Specific Oxygen Uptake Rate method (SOUR-test) (D'Imporzano and Adani, 2007) and (ii) the anaerobic potential biogas production (ABP) (Schievano et al., 2008).

The SOUR-test is a biological aerobic assay. It is a measure of the oxygen uptake rate in an aqueous solution during microbial respiration of a suspended solid matrix. The microbial respiration is measured under standardized moisture conditions and maximized oxygenation and bacteria-substrate interaction conditions, amplifying the differences between different samples. Potential oxygen uptake was measured as the cumulative oxygen demand during the 20 -h test $\left(\mathrm{OD}_{20}, \mathrm{mg} \mathrm{O}_{2} \mathrm{~g} \mathrm{TS}^{-1} 20 \mathrm{~h}^{-1}\right)$. More details about the method are in D'Imporzano and Adani (2007).

The ABP test was performed in a $100-\mathrm{ml}$ serum bottle using $0.62 \mathrm{~g}$ of dried sample added to $37.5 \mathrm{ml}$ of inoculums and $22 \mathrm{ml}$ of de-ionized water. All batches were sealed with Teflon hermetic caps, flushed with an $\mathrm{N}_{2}$ atmosphere, and incubated at $37 \pm 1{ }^{\circ} \mathrm{C}$, until no further biogas production was detected (normally around 60 d). More details are reported in Schievano et al. (2008).

\section{Results and discussion}

\subsection{Chemical characteristics and fiber analyses}

Volatile solids and TOC contents decreased during anaerobic digestion due to the mineralization of part of the organic matter
Table 1

Chemical characteristics of the mixture sampled at different time during the anaerobic digestion.

\begin{tabular}{|c|c|c|c|}
\hline & \multicolumn{3}{|c|}{ Samples group } \\
\hline & $A(n=9)$ & $\mathrm{B}(n=10)$ & $C(n=10)$ \\
\hline TS $\left(\mathrm{g} \mathrm{kg} \mathrm{FM}^{-1}\right)$ & $162 \pm 29$ & $59.1 \pm 16.4$ & $36 \pm 6$ \\
\hline $\operatorname{VS}\left(\mathrm{g} \mathrm{kg} \mathrm{TS}^{-1}\right)$ & $896 \pm 5$ & $751.3 \pm 7$ & $684 \pm 11$ \\
\hline TOC $\left(\mathrm{g} \mathrm{kg} \mathrm{TS}^{-1}\right)$ & $427 \pm 5$ & $404 \pm 18$ & $377 \pm 2$ \\
\hline TKN $\left(\mathrm{g} \mathrm{kg} \mathrm{TS}^{-1}\right)$ & $32 \pm 2$ & $65 \pm 1$ & $110 \pm 1$ \\
\hline $\mathrm{NH}_{3}-\mathrm{N}\left(\mathrm{g} \mathrm{kg} \mathrm{TS}^{-1}\right)$ & $0.52 \pm 0.07$ & $33.3 \pm 0.8$ & $68.4 \pm 1.6$ \\
\hline $\mathrm{C} / \mathrm{N}$ ratio $\left(\mathrm{g} \mathrm{kg} \mathrm{TS}^{-1}\right)$ & $13.43 \pm 0.06$ & $6.74 \pm 0.05$ & $3.43 \pm 0.01$ \\
\hline VFA (g acetic acid $\mathrm{kg} \mathrm{TS}^{-1}$ ) & $47.7 \pm 1.3$ & $51.1 \pm 1.7$ & $18.9 \pm 0.5$ \\
\hline $\mathrm{OD}_{20}\left(\mathrm{mg} \mathrm{O}_{2} \mathrm{~g} \mathrm{TS}^{-1} 20 \mathrm{~h}^{-1}\right)$ & $235 \pm 62$ & $101 \pm 20$ & $30 \pm 20$ \\
\hline $\mathrm{ABP}\left(\mathrm{NL} \mathrm{kg} \mathrm{TS}^{-1}\right)$ & $582 \pm 11$ & $235 \pm 12$ & $77 \pm 8$ \\
\hline $\begin{array}{l}\text { Lignin }+ \text { no hydrolysable lipids ( } \mathrm{g} \mathrm{kg} \\
\mathrm{TS}^{-1} \text { ) }\end{array}$ & $72 \pm 3$ & $201 \pm 7$ & $243 \pm 8$ \\
\hline Hemicellulose $\left(\mathrm{g} \mathrm{kg} \mathrm{TS}^{-1}\right)$ & $27 \pm 2$ & $68 \pm 6$ & $54 \pm 3$ \\
\hline Cellulose $\left(\mathrm{g} \mathrm{kg} \mathrm{TS}^{-1}\right)$ & $71 \pm 2$ & $98 \pm 8$ & $79 \pm 2$ \\
\hline Cell. soluble $\left(\mathrm{g} \mathrm{kg} \mathrm{TS}^{-1}\right)$ & $830 \pm 11$ & $633 \pm 9$ & $624 \pm 10$ \\
\hline
\end{tabular}

contained in the ingestates (Table 1). The total VS and TOC degradation during the process amounted to $75 \%$ and $71 \%$, respectively. The $\mathrm{pH}$ of the ingestate was very low ( $\mathrm{pH}$ of 3.68) due to the high presence of volatile fatty acids (VFA) (Table 1). Following anaerobic digestion, the $\mathrm{pH}$ increased to 8.65 as a consequence of VFA degradation and ammonia production (Melamane et al., 2007) (Table 1). Due to the TOC degradation and nitrogen concentration, the $\mathrm{C} / \mathrm{N}$ ratio decreases from 13.43 in the ingestate to 3.43 in the digestate.

Anaerobic digestion proceeded through the degradation of the readily available organic matter, i.e. a total reduction, with respect initial mass, of $75 \%$ of cell soluble, $63 \%$ of cellulose and $58 \%$ of hemicellulose, and preservation of the more recalcitrant fractions (lignin and non-hydrolysable lipids), i.e. increasing, with respect initial mass content, of $9.5 \%$.

\section{2. ${ }^{13} \mathrm{C}$ CPMAS NMR analysis}

${ }^{13} \mathrm{C}$ CPMAS NMR provides qualitative and quantitative information on the composition of the ingestate and digestate by identifying the main C-type of which the organic matter consists (Conte et al., 1997). Five types of carbon can be distinguished in the NMR spectrum (Table 2): (i) short chain aliphatic carbon (e.g. volatile fatty acid and steroid-like molecules) (Réveillé et al., 2003) (0-28 ppm); (ii) long chain aliphatic carbon (e.g. plant aliphatic biopolymers) (Pereira et al., 2005) and proteins (Dignac et al., 2000) (28-47 ppm); (iii) O-alkyl carbon (e.g. polysaccharides) (Kögel-Knabner, 2002) (47-113 ppm); (iv) aromatic carbon (e.g. lignin) (Ussiri and Johnson, 2003) (113-160 ppm) and (v) carbonyl carbon in aliphatic esters, carboxyl groups and amide carboxyl (160-210 ppm).

The NMR spectrum of the ingestate was dominated by polysaccharides (47-113 ppm). The decrease of this area (Table 2) during the anaerobic digestion agrees with fiber analyses data and confirmed that the process proceeded mainly through the degradation of carbohydrate-like molecules. As a consequence of this, the aromatic-C (113-160 ppm) and above all long chain aliphatic-C (28$47 \mathrm{ppm}$ ) contents increased due to their recalcitrant nature (Pichler et al., 2001; Ussiri and Johnson, 2003). The increase of the area at $160-210 \mathrm{ppm}$ (carboxyl group of the aliphatic chain) confirms this trend. More complicated was the interpretation of the region relative to the short aliphatic carbon $(0-28 \mathrm{ppm})$ that apparently did not show appreciable modification. According to the chemical analysis (Table 1), a strong reduction of the VFA content occurred during $A D$ process, should lead to a relative reduction of this area (a strong reduction of the peak at $21 \mathrm{ppm}$ attributed to the VFA confirmed this hypothesis) (data not shown). On the other hand the new peaks registered in the digestate at $14 \mathrm{ppm}$ and 24- 
Table 2

${ }^{13} \mathrm{C}$ CPMAS NMR integrated area of different carbon type of mixtures sampled at different time during the anaerobic digestion.

\begin{tabular}{|c|c|c|c|c|c|}
\hline & & \multirow[t]{2}{*}{ Band $\delta$ range (ppm) } & \multicolumn{3}{|c|}{ Sample group } \\
\hline & & & A & B & $\mathrm{C}$ \\
\hline \multirow[t]{2}{*}{ Aliphatic $\mathrm{C}$ bonded to other aliphatic chain or to $\mathrm{H}$} & Short chain & $0-28$ & 13.95 & 14.82 & 16.46 \\
\hline & Long chain & $28-47$ & 7.82 & 24.26 & 27.30 \\
\hline Total aliphatic $\mathrm{C}$ & & $0-47$ & 21.77 & 39.08 & 43.76 \\
\hline $\mathrm{O}-\mathrm{CH}_{3}$ or $\mathrm{N}$-alkyl O-alkyl-C di-O-alkyl-C & & $47-113$ & 65.50 & 42.01 & 36.75 \\
\hline Aromatic C phenol or phenyl ether $C$ & & $113-160$ & 4.81 & 9.07 & 8.17 \\
\hline Carboxyl C keto C & & $160-210$ & 7.92 & 9.84 & 11.32 \\
\hline
\end{tabular}

$25 \mathrm{ppm}$ (data not shown) indicated the concentration of recalcitrant short chain aliphatic-C, i.e. steroid-like molecules, derived from cow slurry (Réveillé et al., 2003).

\subsection{Biological stability}

The oxygen uptake rate decreased a lot during the process as represented by the low $\mathrm{OD}_{20}$ value measured in the digestate (Table 1 ) which resembled that of mature composts (Scaglia et al., 2007).

The anaerobic potential biogas production of the stabilized sample decreased (Table 1 ), correlating with the $\mathrm{OD}_{20}$ measured $(r=0.95 ; P<0.05)$. This means that the measurement of the cumulative oxygen uptake rate provided results similar to the biogas test but in a much shorter time (2d) than the ABP test (60 d) (Schievano et al., 2008), and therefore can be considered an useful and fast test to measure the biological stability in digestates.

The cumulative oxygen uptake rate $\left(\mathrm{OD}_{20}\right)$ (Table 1$)$ correlated strongly with the sum of cellulose + hemicellulose + cell soluble contents, detected by fiber analysis (Table 1$)(r=0.99 ; P<0.05)$, and with both O-alkyl-C $(r=0.98 ; \quad P<0.05)$, and alkyl-C $(r=-0.99 ; P<0.05)$ fractions, detected by ${ }^{13} \mathrm{C}$ CPMAS NMR. This suggests that the degradation of more degradable carbohydrates and the preservation of foremost lipids and more recalcitrant lignin were responsible for the high biological stability on the digestate. Therefore qualitative/quantitative modification of ingestate organic matter during the anaerobic process, accurately described the increasing biological stability, providing useful information to better qualify and interpret the nature of the digestate in relation to its use as organic amendment.

\section{Conclusions}

Anaerobic digestion performed on mixtures of energetic crops, cow slurry, agro-industrial waste and the organic fraction of MSW determined the relative concentration of more recalcitrant organic molecules. The qualitative/quantitative modification of ingested organic matter led to an increase of the biological stability.

Results obtained suggested digestate as good candidate to act as organic amendment. Nevertheless both the amendment properties of the digestate and the potential impacts of it will need to be investigated by field application of the digestate in soil to evaluate its effect on the soil nutrient status (nutrients properties) and humic substance balance (amendment properties).

\section{Acknowledgements}

This study was supported by ARAL - Associazione Regionale Allevatori della Lombardia and Lombardy Region. The authors are grateful to Dr. Luca Malagutti for the fiber analyses and ABP determinations.

\section{References}

APHA, 1992. Standard Methods for the Examination of Water and Wastewater, 18th ed. American Public Health Association, Washington, DC, USA.

Conte, P., Piccolo, A., Van Lagen, B., Buurman, P., de Jager, P.A., 1997. Quantitative aspects of solid-state ${ }^{13} \mathrm{C}$-NMR spectra of humic substances from soils of volcanic systems. Geoderma 80, 327-338.

Dignac, M.F., Derenne, S., Ginestet, P., Bruchet, A., Kniker, H., Largeau, C., 2000 Determination of structure and origin of refractory organic matter in biodepurated wastewater via spectroscopic methods. Comparison of conventional and ozonation treatment. Environ. Sci. Technol. 34, 3389-3394.

D'Imporzano, G., Adani, F., 2007. The contribution of water soluble and water insoluble organic fraction to oxygen uptake rate during high rate composting. Biodegradation 18, 103-113.

Genevini, P.L., Adani, F., Villa, C., 1997. Rice hull degradation by co-composting with dairy cattle slurry. Soil Sci. Plant Nutr. 43 (1), 135-147.

Hansen, K.H., Angelidaki, I., Ahring, B.K., 1999. Improving thermophilic anaerobic digestion of swine manure. Water Res. 33 (8), 1805-1810.

IRSA CNR, 1994. Metodi analitici per le acque, Quaderni, N. 100. Istituto Poligrafico e Zecca dello Stato, Rome, Italy.

Kögel-Knabner, I., 2002. The macromolecular organic composition of plant and microbial residues as inputs to soil organic matter. Soil Biol. Biochem. 34, 139162.

Lasaridi, K., Stentiford, E.I., 1998. A simple respirometric technique for assessing compost stability. Water Res. 31 (12), 3717-3723.

Magdoff, F., Weil, R.R., 2004. Soil organic matter management strategies. In: Magdoff, F., Weil, R.R. (Eds.), Soil Organic Matter in Sustainable Agriculture. CRC Press, New York, pp. 45-65.

Melamane, X., Tandlich, R., Burgess, J., 2007. Anaerobic digestion of fungally pretreated wine distillery wastewater. Afr. J. Biotechnol. 6, 1990-1993.

Pereira, M.A., Pires, O.C., Mota, M., Alves, M.M., 2005. Anaerobic biodegradation of oleic and palmitic acids: evidence of mass transfer limitations caused by long chain fatty acid accumulation onto the anaerobic sludge. Biotechnol. Bioeng. 92 15-23.

Pichler, M., Knicker, H., Kögel-Knabner, I., 2001. Solid-state ${ }^{13} \mathrm{C}$ NMR spectroscopic chemolytic and biological assessment of pretreated municipal solid waste. J Ind. Microbiol. Biotechnol. 26, 83-89.

Réveillé, V., Mansuy, L., Jardé, E., Garnier-Sillam, E., 2003. Characterization of sewage-sludge derived organic matter: lipids and humic acids. Org. Geochem. 34, 615-627.

Scaglia, B., Erriquens, F.G., Gigliotti, G., Taccari, M., Ciani, M., Genevini, P.L., Adani, F. 2007. Precision determination for the specific oxygen uptake rate (SOUR) method used for biological stability evaluation of compost and biostabilized products. Bioresour. Technol. 98, 706-713.

Schievano, A., Pognani, M., D'Imporzano, G., Adani, F., 2008. Predicting anaerobic biogasification potential of ingestates and digestates of a full-scale biogas plant using chemical and biological parameters. Bioresour. Technol. 99, 81128117 .

Tani, M., Sakamoto, N., Kishimoto, T., Umetsu, K., 2006. Utilization of anaerobically digested slurry combined with other waste following application to agricultural land. Int. Congr. Ser. 1293, 331-334.

Ussiri, A.A.N., Johnson, C.E., 2003. Characterization of organic matter in a northern hardwood forest soil by ${ }^{13} \mathrm{C}$ NMR spectroscopy and chemicals methods. Geoderma 11, 123-149.

Van Soest, P.J., Robertson, B.A., Lewis, B.A., 1991. Methods for dietary fiber, neutra detergent fiber and nonstarch polysaccharides in relation to animal nutrition. J. Dairy Sci. 74, 3583-3597.

Zhang, R., El-Mashad, H.M., Hartman, K., Wang, F., Liu, G., Choate, C., Gamble, P., 2007. Characterization of food waste as feedstock for anaerobic digestion. Bioresour. Technol. 98, 929-935. 